\title{
Improving Speaking Competency of The Students at SMK N 4 Bangli Using Project-Based Learning
}

\author{
Luh Putu Ayu Novita Dewi \\ Jurusan Pendidikan Bahasa Inggris \\ Universitas Pendidikan Ganesha \\ Singaraja, Indonesia \\ e-mail: oviekawai@gmail.com
}

\begin{abstract}
This study aimed at improving speaking competency of the students using project-based learning. The subjects of this study were the eleventh grade AP1 students of SMK Negeri 4 Bangli which consisted 25 students. The study was conducted by following the action research procedures and it was completed in two cycles. The result of the study showed that speaking competency of the students could be improved by using project-based learning. The result of post-test 2 proved that the students' mean score was 80 which significantly improved from the pre-test result that was 69 . The class percentage of the students passing the test was $100 \%$ which was beyond the expectation which was $75 \%$. Based on the questionnaire, the students also had positive response towards the implementation of project-based learning. The result showed that learning English using project-based learning could improve their speaking competency in terms of fluency, pronunciation, grammar, and vocabulary.
\end{abstract}

Keywords: Project-based learning, speaking competency

\section{INTRODUCTION}

Basically, communication with other people is particularly the goal of learning a language. There are many languages in the world that are used for communication. English is one of the languages which is admitted as an international language in the world. As a result, many schools put English as one of the subjects in their curriculum in order to enable the students to communicate with others by using English.

In mastering English, there are four important skills namely: listening, speaking, reading, and writing. Therefore, by mastering the four language skills (listening, speaking, reading, and writing), the students will develop their competences in the process of teaching and learning process. However, based on the investigation, the students still had problems in speaking competency. This study was conducted in the eleventh grade AP1 students of SMK N 4 Bangli. In speaking, the students sometimes made varieties of mistakes. For instance, they felt afraid to express their ideas as directly in front of the class because they had low confidence.

Therefore, the researcher conducted the pre-test to find out speaking competency of the eleventh grade AP1 students, by asking them to explain "how to make something". The task was: "Can you tell me what your favorite juice is? And how to make it! Then explain the steps how to make your favorite juice to your friends!" All of the students were given chance to speak in front of the class. The following table showed data of students in speaking competency. 
Table 1. Percentage of Students' peaking Competency in Pre-Test

\begin{tabular}{llll}
\hline No & $\begin{array}{l}\text { Performance } \\
\text { Indicator Category }\end{array}$ & \multicolumn{2}{l}{$\begin{array}{l}\text { Students' } \\
\text { Competency }\end{array}$} \\
\cline { 3 - 4 } & & $\mathrm{f}$ & $\%$ \\
\hline 1 & $\geq 72$ & 7 & $28 \%$ \\
\hline $2 \quad \leq 72$ & 18 & $72 \%$ \\
\hline \multicolumn{2}{l}{ Total } & 25 & $100 \%$ \\
\hline
\end{tabular}

In the preliminary observation, the score showed that there were 7 (28\%) students who gained score above the passing grade 72 in speaking while there were $18(72 \%)$ students who gained score below the passing grade 72 in speaking. In other words, there were 18 (72\%) students had difficulties of speaking. The mean score of students in preliminary test was 69 . The main score got from the totalling the students' total score divided with the total number of the students.

According to the students problems and the results in preliminary test, project-based learning (PBL) is one of the approaches recommended to be used to solve the problems of the eleventh grade AP1 students. PBL refers to an approach allowing "students to design, plan, and carry out an extended project that produces a publicly exhibited output such as a product, publication, or presentation" (Patton, 2012, p.13).

The use of project- based learning approach has several advantages towards the students' speaking skill. First, it improves the students' speaking skill in oral communication. Second, the use of project-based learning approach in teaching speaking could increase students' motivation and interest in learning English especially for speaking skill. By using a fun treatment and not too formal, students will like the learning atmosphere. Third, project-based learning approach requires cooperation with other students in group so that students learn how to work together to achieve the goal and how to solve the problem (Khotimah, 2014, p.55)

Based on the discussion above, the researcher found that all of the items appropriated for the students to improve their speaking competency in criteria of fluency, pronunciation, grammar, and vocabulary. Therefore, in this study, the researcher used PBL approach to solve the students' problem in choosing and arranging the words into a good organization. The subjects of this study were 25 students in XI AP1 class of SMK N 4 Bangli in academic year 2015/2016.

Ur (1996) states that speaking is the most important skill among four skills (listening, speaking, reading, and writing) because people who know a language are referred to as speakers of that language. Brown (2010, p.183) states that speaking is productive skill that can be directly and empirically observed, those observations are invariably color by accuracy and effectiveness of a test-taker's listening skill, which necessarily compromises the reliability and validity of an oral production skill.

From the explanation above, the researcher conclude that speaking is important skill to communicate with other people directly which produce words and sounds that should be meaningful to express ideas, feelings, and thoughts.

It is very important for students to build their confidence to express ideas and opinions in speaking. Consequently, speaking skill should be mastered by the learners of language. Following are the elements of speaking ability according to Ur (1996) as cited in Hosni (2014) students have problems in speaking activities, such as inhibition, low motivation, mother tongue use, and nothing to say.

According to Harmer (2001, p.269) there are four elements that are important for students in speaking English. Those elements are connected speech, expressive devices, lexis and grammar, and negotiation language. The connected speech is the modified sounds production or utterances. The expressive device is the alteration of the speed, volume, and stress of utterances to show the feeling. And it is useful to convey meaning. Then, the lexis and grammar is important in order to certain words and language function, such as agreeing or disagreeing. And the negotiation language is needed for clarifying and showing the structure of 
the words. Therefore, those elements are completely should be pay attention in speaking skills.

Project is defined as complex tasks based on problems encountered by students, conducted in certain periods of time and culminated in realistic products that might be in form of presentation, exhibition, publication, etc. (Thomas, 2000 , p.1). The project is supposed to be long-term, requires teamwork among students, and results in a substantial final product (Cruz \& Vik, 2007 as cited in Maulany, 2013, p.32). Simply, project is an evidence of students' effort in learning process during period time.

According to Blumenfeld at al., (1991, p.371), Project-Based Learning is comprehensive perspective focused on teaching by engaging students in investigation. In addition, Thomas (2000) defines project-based learning as a model of learning that organizes learning around projects. Through project-based learning, students find solutions to real world problems by asking questions, designing and conducting investigations, researching problem, gathering information, drawing conclusions based on the findings, and reporting results (Schneider, Krajcik, Marx, \& Soloway, 2002, p. 411).

Therefore, the researcher tries to conclude that definition of Project-Based Learning is a learning approach that raises students to gain knowledge and skill by giving them opportunity to work individually or cooperatively to produce a realistic product or presentation from their learning experiences. According to Thomas (2000), there are five criteria of Project-Based Learning, namely; centrality, driving question, constructive investigations, autonomy, and realism.

a. In PBL, projects are central, not peripheral to the curriculum. It means that the project is the central teaching strategy; students encounter and learn the central concepts of the discipline via the project.

b. In PBL, projects are focused on questions or problems that "drive" students to encounter (and struggle with) the central concepts and principles of a discipline. Simply, the students have to take responsibility to solve their problems.

c. In PBL, projects involve students in a constructive investigation. So, an investigation is a goal-directed process that involves inquiry, knowledge building, and resolution.

d. In PBL, projects are student-driven to some significant degree. It means that projects incorporate a good deal more student autonomy, choice, unsupervised work time, and responsibility than traditional instruction and traditional projects.

e. In PBL, projects are realistic, not school-like.

Therefore, these characteristics can include the topic, the tasks, the roles that students play, the context of the project is carried out, the collaborators which work with students on the project in form of product, and the performances.

\section{RESEARCH METHODS}

In this study, the researcher used classroom action research. The research was cycling process involving the steps of identifying a question or problem, planning, acting, observing and reflecting (Mettetal, 2001, p.8). Here the figure of the iterative action research process:

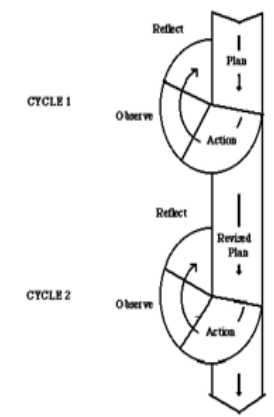

Figure 1. Iterative action research process

Classroom action research is a very effective way to improve teaching and learning process. In this case, the researcher conducted research based on problems of students' speaking competency by using Project-Based Learning. The research method was used to find out the result of students' performance in speaking after applying Project-Based Learning. 
The research procedure consisted of planning, action, observation and reflection. Before conducting a treatment, the writer conducted preliminary observation consisting of a pre-test, a semi unstructured-interview and class observation.

The setting of this study was SMK N 4 Bangli. It is located on Nusantara Street Kubu, Bangli. The subjects of this study were the eleventh grade AP1 students of SMK N 4 Bangli in academic year 2015/2016. The subjects were 25 students consisted of 20 males, and 5 females.

There were two cycles employed in this research. Each cycle consisted of four times meeting. The first, the second, and the third meeting were used for teaching the students using the project-based learning approach, while the forth meeting was used for conducting the test. There were some instruments used in each cycle. They were researcher's diary, posttests and questionnaires. Each cycle consisted of panning, action, observation and reflection.

The data were obtained from interview, observation, the pre-test, posttest, questionnaire and researcher's diary. Interview, observation and pre-test were conducted before teaching. The results of all of them were used as guidance for conducting the research. And post-test was conducted after teaching. It was conducted to see if the students' speaking competency be improved or not after the given the treatment. And then questionnaire was given after teaching. It was given to find out the students' responses towards the implementation of project-based learning. And the last, the researcher's diary was used to record all activities running in each session.

The data were analyzed qualitatively and quantitatively. The qualitative data were obtained from the result class observation, researcher's diary and the questionnaire about the students' responses towards the implementation of project-based learning. Meanwhile, the quantitative data were obtained from the result of pre-test which was done before teaching and post-test which was done after teaching.
This study was considered successful if $75 \%$ out of the total sum of the students could pass the score passing grade which was 72 . If $75 \%$ of the students could pass the test, it means the implementation of PBL approach could significantly improve the students' speaking competency. In other words, the cycle of this study could be stopped.

\section{FINDINGS AND DISCUSSION}

As stated before, the eleventh grade students of SMK N 4 Bangli in class $\mathrm{XI}$ AP1 faced problems in their speaking competency. The problem that became main concern of this study was their ability in delivering ideas in a good organization orally. Project-Based Learning approach was applied in this study in order to improve the student's speaking competency and conducted in two cycles that consist of 3 sessions for action and 1 session for post-test in each cycle.

There were two kinds of data obtained in this study, such as; quantitative data and qualitative data. The quantitative data were obtained from the number of scoring by each student in pretest, post-test 1, and post-test 2 . Descriptive analysis was used to support the data more obviously. In analyzing the data, the score obtained by subject and the students' mean score on pre-test, post-test 1, and post-test 2 were described and compared to find out whether the student's speaking competency improved or not. To ensure the analysis, the students were giving a test to measure their speaking competency. The speaking test was presentation based on their project in a group. Although, they made their project in a group, but all of the students analyzed as individually for their improvement in every sub skills in speaking, such as; fluency, pronunciation, grammar, and vocabulary.

All data on pre-test, post-test 1, and post-test 2 were shown in form of tables in the discussion sessions. The qualitative data which were obtained from the result of questionnaire and researcher's diary supported the quantitative findings. The researcher's diary was written a long process of the 
data collection and the questionnaires were handed after the tests were conducted. Furthermore, this study was also intended to find out the student's response to the implementation of projectbased learning approach.

The pre-observation was conducted on Saturday, August 4th, 2015. It was done in order to obtain an overview the process of teaching speaking competency. The observation was conducted by observing the English teacher who was teaching in class XI AP1. The teacher applied conventional teaching technique by giving the students material based on the book. And the task was also taken from the book. She asked the students to open the book and gave opinion about the text that was written on the book. She gave an example how to give opinion about the text that was written on the book. Then, she asked the students to do what the teacher had modeled before. After the students gave their opinions as directly about the text on the book, the teacher asked the other's students opinion without gave feedback to the students. The classroom condition was not challenging and interesting. Most of the students looked bored and some of students did not focus on the material and they chatted with their classmates. The teacher applied an individual test as assessment. The teacher assessed the students' performance based on their speaking. The teacher ended the class by concluding the lesson but did not give feedback on what they have learnt. The class only dominated by the teacher.

Observation on the teaching and learning process showed that the class less of interactive between the teacher and the students. They seemed to be less to be motivated in performing their speaking's competency in term of their fluency, pronunciation, grammar, and vocabulary. Most of the students had difficulties to express their thought to be good organization. They often repeated the same ideas and waited for the same time with other friends who were smarter. They did not have motivate to improve their speaking' competency because there was not a good challenge in that lesson.
After the English class finished, the researcher tried to interview two students in class XI AP1 in an informal situation. They said that they feel not enthusiastic during the lesson because they did not need any effort to give opinion based on the task given. They just waited for the smart students to perform first and then just listen and repeat what the previous students had done.

Based on the classroom observation, the researcher conducted the pre-test. From the pre-test given, the result showed that there were $7(28 \%)$ students could pass the test based on the passing grade, while there were $18(72 \%)$ students who failed the test. In other words, the mean score of students was only 69 in the pre-test. Therefore, further study needed to be conducted. Moreover, the students must be given further treatment for the purpose of improving their speaking competency.

After conducting the pre-test, the questionnaire was given to the students to ensure the finding that was found from the pre-test result. The questionnaire consisted of 10 multiple choice items. The pre-questionnaire was given to know the students' problem and the respond in speaking's competency.

Based on the results of observation, pre-test, and questionnaire, the researcher could conclude that most of the students' mean score in speaking competency was low. It indicated that the students could not express their ideas in a good organization and content because they had no idea to be spoken.

\section{Cycle I}

Planning was the first part of the cycle which was done before teaching and learning process. The researcher needed some preparations before applying the treatment to the students. Firstly, the researcher selected appropriate material. The material was "Procedure Text". Second, the researcher set up teaching scenario and scoring rubric. The researcher planed the students' evaluation in form of presentation.

Action was the implementation of the planning having been previously 
planned by the researcher. Here, the researcher divided the students into 5 groups, 1 group consisted of 5 students in which they were given a different topic. The researcher gave the learning task to the students to investigate the special food in Bangli regency. Then, the researcher asked the students to make preparation about the investigation of their projects. Students discussed with their group members. The students exhibited their final project in form of presentation or performance. After that, the researcher assessed the students' projects based on their competency and effort.

The researcher observed the students' responses when the researcher used the strategy. Besides the responses, the situation and the behavior of the students were also observed by the researcher and noted in the researcher's diary. After the action, the result of the questionnaires and the speaking test analyzed. From the analysis of the speaking test, the researcher found the result of the action whether the students' speaking skill improved or not.

Post-test was given at the end of the teaching. It was handed out to find out the students' speaking competency after the given treatment. There were 25 students following the post-test.

From the calculation of students' posttest I score, it could be inferred that there was an improvement toward students' speaking competency after the implementation of project-based learning. From the result of the mean score of pretest and post-test 1 showed that the mean of pre-test was 69 while the mean of the post-test I was 73 . It means there were 4 points improving toward students' speaking score. From the Post-test 1 result remained that 17 of 25 students had passed the passing grade which was 72 .

From the explanation above showed that the students' speaking competency improved after the implementation of the project-based learning, however it still did not get the researcher's expectation. Therefore, the researcher conducted the second cycle.
In order to know the students' responses toward the application of Project Based-Learning approach, the researcher gave questionnaire to the students. It consisted of 10 items multiple choices.

The results from the researcher's diary were satisfying. Most of the students were enthusiastic towards the application of PBL. All the students felt that this kind of learning approach was very challenging and gave them a lot of chance to get new information outside of the classroom. Besides, the class discussion also involved in the learning process that promoted the students to express their ideas freely with low anxiety.

Based on the 1st cycle treatments, it could be seen that the teaching and learning activities ran well as what it was planned and the result was also satisfying enough.

The researcher found that there were weaknesses in implementation of PBL approach in this cycle, such as the low students still had difficulties to reach the standard score. They could not express their ideas in a good organization. It was caused that this application was only the first time to be implemented. Then, during the presentation several students did not give their attention to their friends who performed in front of the class.

The researcher continued to next cycle (cycle 2). In the cycle 2 carried out by modifying the technique. The researcher used a role-play situation where the students acted as a staff of tourism and culture in Bangli in which to promote kinds of the handicraft in Bangli. Every group had to make a report in term of procedure text about one kind of the handicraft made in Bangli.

In discussion session, the researcher asked the students one by one to share their all of the information and their experienced during the investigation so that every student had responsibility with their tasks. By giving the students chance to speak one by one in the discussion session, made the students motivated to practice their speaking. Therefore, they could express their ideas fluently. The researcher helped the students when they 
got mistakes in pronunciation, grammar and vocabulary.

\section{Cycle II}

In cycle 2, the researcher modified the treatment to improve the students' achievement and also to follow up the analysis and reflection in cycle 1 . As what the researcher did in the previous cycle, the researcher did the action based on the research stages that included planning, acting, observing, and reflecting. Therefore, the researcher conducted cycle II to improve things that have not been obtained in cycle I yet. To make the teaching and learning process be satisfactory and achieve the target score, the researcher revised the previous lesson plans used in cycle I. The presented material was still the same as cycle I which was about "procedure text". There was a little difference in terms of the activities conducted. In this case, the researcher made modification of the situation in the oral presentation.

The researcher used role-play situation in which the students acted as a staff tourism and culture from Bangli. It purposed to promote kinds of handicraft from Bangli. And they had a report their project based on their investigation in form of presentation. In the discussion session, the researcher asked the students one by one to share their information and their experiences during the investigation. By giving the students chance to speak about their opinions one by one made the students practiced their speaking competency. The researcher also helped and corrected their mistakes as directly.

In this action, the application of PBL approach was implemented with several corrections which had been mentioned before. Then, the researcher divided the students into 5 groups, 1 group consist of 5 students in which each group had different topic. The researcher asked the students to pretend to be a staff of tourism and culture from Bangli in which they had to promote kinds of handicraft from Bangli. In discussion sessions, the researcher asked one by one of the students to share their information and their experiences during an investigation. So that, every students had chance to practice their speaking competency. The students exhibited their final project in form of presentation or performance. The evaluation in cycle 2 was not too different from the previous cycle. The researcher gave feedback for the students during an investigation in real life situation.

The next phase is observation. In this phase, the researcher's duty was still the same in which he observed and noted every single thing taking place during the process of teaching and learning. Here the researcher as well acted as a teacher giving the treatment to the students. In some occasions, while teaching the students, she noted every important aspect found involving classroom situation, students' behavior and responses in a particular activity conducted. As the result of the notetaking, the students seemed to be having enthusiastic in the classroom activity. They were so excited especially when the researcher asked the students to act like a staff of tourism object and culture which promoted kinds of the handicraft from Bangli. Each group was free to choose which kind of handicraft to take the data. Every group discussed with their members' group. This project aimed to direct the students to promote kinds of the handicraft from Bangli because the researcher wanted the students got new experienced in real life situation and gave challenging activities outside of classroom. Furthermore, the students treated their ideas in speaking competency. Besides the class situation is very conducive. The students were no longer afraid to express their opinions. They looked enthusiastic to share their experiences in form of presentation.

Based on the results of the second cycle's treatments, it could be reflected that teaching and learning activities was really good and gave benefits for the students' competency in speaking. From the data gained, the students' speaking competency in the test showed successfully improvement. The students' mean score in post-test 2 was 80 from73 in post-test 1 . There were 25 students' mean score obtained improvement was 7 
in post-test 2. The improvement also happened in every sub skills of speaking. The mean score of the students in termed of fluency in post-test 2 was 4.2 from 3.8, in termed of pronunciation in post-test 2 the students gained 3.9 from 3.7, the mean score of the students in termed of grammar in post-test was 3.9 from 3.6, and in termed of vocabulary in post-test 2 , the students gained 3.9 from 3.4. Based on the results, it could be said that in every sub skills of speaking the students gained significant improvement. The students' sub skills in termed of fluency had the most significant improvement. All of the students gave good responses toward the application of PBL approach. They looked really enthusiastic during the project given because they could get new experience and a lot of information outside the classroom.

Besides, the result of the questionnaire was really positive. The students loved to be involved in the activity during the application of PBL approach. They felt that their competency in speaking improved. It was shown by their expressing in deliver the ideas in a good organization without anxiety.

Based on the analysis, the application of PBL approach improved the students' speaking competency. From the result, of the last test, $100 \%$ of the students reached the standard score of passing grade which was 72 . Since this study was considered as successful, the study was finished in this cycle. It means that the application of PBL approach treated the students' interest in studying, and also reduced their anxiety in speaking English.

This phase discussed about the result of post-test II. There were 25 students joining the test. There was a significant improvement on the students' speaking competency. Their grand mean score was 80 meaning that the expected target was achieved. All the students could successfully pass the test based on the school passing grade which was 72 .

The students' achievement of each sub skills in speaking made significant improvement in post-test 2 . Specifically, in terms of fluency, the data showed that the students' mean score in post-test 2 was increased from 3.8 to 4.2 . It could be seen that the students' mean score in term of fluency was significant improvement. The improvement of fluency showed that 0.6 points.

In terms of pronunciation, the students' mean score improved from 3.8 in pre-test to 3.9 in post-test 2 . It showed that the students' mean score in pronunciation was categorized as sufficient with 0.2 point improved in post-test 2.

In terms of grammar, the students' mean score improved from 3.6 in post-test 1 to 3.9 in post-test 2 . The students' mean score in grammar was categorized as sufficient. The improvement of grammar showed that 0.2 point improved in posttest 2.

In terms of vocabulary, the students' mean score improved 3.4 in pre-test to 3.9 in post-test. The students' mean score in vocabulary was categorized as sufficient with 0.3 point improved in post-test 2 .

the percentage of the students passing the test on pre-test was $28 \%$, there was significant improvement in the percentages of the students passing the test on post-test 1 was $68 \%$, and there was successfully improvement in the percentages of the students passing the test on post-test 2 was $100 \%$.

Overall, it showed that the students already gained significant improvement. Therefore, all the students got experiences from the benefits of the application PBL approach.

\section{CONCLUSION}

Based on the result of data analysis, the researcher inferred that teaching English by using project-based learning is effective and could improve the students' speaking competency. The project gave a challenge activity to the students. They were interested in and happy to speak English by finishing the project. Besides, the activity of group discussion created a good interaction with their friends in small group before they spoke in front of the class. Therefore, they could more confidence to speak English in front of the class. 
Based on the conclusion above, there are some suggestions which are presented to improve students' speaking skill. Firstly, working together in group is one of the methods that can be applied in teaching speaking. Teachers should have interesting techniques to teach their students, for example by using discussion technique. Implementation of projectbased learning approach provides problem to be discussed, it will help the students to be more talkative in their environment and train them to be critical.

Besides, using project-based learning could increase students' motivation to learn more in fun activities because they can improve their speaking competency in and outside the classroom.

Furthermore, students need to be more active in learning speaking. They have to be active in every opportunity that requires them to speak in English. Practicing is the best way to learn English, it will make them more fluent in speaking and improve their self-confidence.

Lastly, for English teachers is highly recommended to use project-based learning approach in learning process for their purpose in speaking competency.

\section{REFERENCES}

Brown, H. Douglas. (2010). Language assessment principles and classroom practice. Second Edition. New York: Pearson Longman.

Blumenfeld, P. C., Soloway, E., Mark, R., W., Krajcik, J., S., Guzdial, M. \& Palincsa, A. (1991). Motivating project-based learning: sustaining the doing, supporting the learning. Educational Psychologist. Educational Psychologist, 26 (3 \& $4)$ 369-398. The University of Michigan. Retrieved from http://mathforum.org/wikis/uploads/BI umenfeld.motivating.project.based.p df

Harmer, J. (2001). The Practice of English Language Teaching ELT Journal, 57(4), 269-370.

Hosni, A. L. (2014). Speaking difficulties encountered by young EFL learners.
Khotimah, S. (2014). "The use of problem based learning to improve students' speaking ability". Journal of English Language Teaching, 3(1), 50-56. Retrieved from http://journal.unnes.ac.id/sju/index.p $\mathrm{hp} / \mathrm{elt}$

Maulany, D. B. (2013). The use of projectbased learning in improving the students speaking skill. Journal of English and Education, 1 (1), 3042. Retrieved from http://www.ejournal.upi.eud/index.ph p.L-E/article/view323.pdf

Mettetal, G. 2001. The what, why and how of classroom action research. The Journal of Scholarships of Teaching and Learning (JoSoTL), 2(1), 6-13. Retrieved from http://josotl.indiana.edu/article/viewFi le/1589/1588

Patton, A. (2012). Work That Matters: The Teacher's Guide to Project-Based Learning. The Paul Hamlyn Foundation.

Schneider, R. M., Krajcik, J., Marx, R. W., \& Soloway, E. (2002). Performance of students in project-based science classrooms on a national measurement of science achievement. Journal of Research in Science Teaching, 39(5), 410422. Retrieved from http://www.umich.edu/ hiceweb/pap ers/2001/performance/Schneider_N AEP.pdf

Thomas, J. (2000). A review of research on PBL. Journal of educational development, 1-48. Retrieved from http://www.bobpeartman.org/BestPra ctice/PBL.Research.pdf

Ur, P. (1996). A course in language teaching: practice and theory. New york: Cambridge

University Press. International journal on studies in English language and literature (IJSELL), 2 (6), 22-30. Retrieved from www.arcjournal.org 